\title{
POŚTA
}

TELEKOMUNIKÁCIE A

ELEKTRONICKÝ OBCHOD

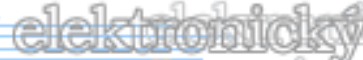

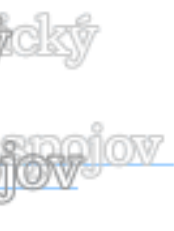

\section{SYSTEM APPROACH FOR RECONSTRUCTION OF THE NATIONAL POSTAL SYSTEMS}

\author{
Pero Tabak*
}

\section{Introduction}

In 2008 the European Parliament is accepted the final changes of Postal Directive (97/67/EC) which established the general rules for the development internal postal market and improves the quality of Community postal services. All EU member states have obligation to implement mandatory provisions of the Directive into their national legislation until 2011 or 2013. Shortly, Member States must ensure universal postal obligation (with minimum set of postal service) throughout the country with the approved funding mechanisms (and with the separated cost accounting), full market opened (which means ensure effective competition among all providers throughout the territory) but in the same time, protect the interests of all postal service users, ensure the quality of universal services in accordance with the harmonized European standards and establish a national regulatory body to carry out the obligations arising from the Directive. [1]

On the other hand, the Directive does not impose obligations to Member States, for example, how to restructure the national postal system, prepare national postal operators for full market opened (FMO) or produce national postal strategy. Listed and non-listed activities could be considered as consequence of the obligations which are arise from Directive and therefore each Member States, according to its county specific (tradition, geographic structure, development, postal traffic,...) must find own way to conduct those activities in order to create and harmonize national postal market into the single European market. However, from the actual postal practices we could see two approaches, one where the Member States recognize and established the national strategy of postal system then restructured the national postal operator and the other, where Member States with a delay only formally adopted a development strategy, only partly restructure the national postal provider (more preparing for privatization than for the competition), while the vision of its own postal system in the future, those Member State haven’t well know defined.

\section{Postal system and the single European market}

There are two terms which have to be preliminary clarified: the postal system and the single European market. Postal system is a structured complex entity with the main task to ensure transfer of addressed material entities from the sender to the addressee. Certainly this definition would be able to expand at will, from the fact that "addressed material entities" are postal items, that the system allows the transmission for all users under the same conditions

\footnotetext{
* Pero Tabak, , Postal expert in Croatian NRA and professor on University of Zagreb, Faculty of transport and traffic science, Postal Dep., Zagreb.E-mail: ptabak@hakom.hr, ptabak@fpz.hr
} 
(the public principle), that for transmission is required the public postal network, ... However, any wider explanation of the definition could be lead to its entropy, for example, when the addressed material entity is postal item (or courier item) or when this same material entity is road, railway and air item (or even money order item), why all users should be used services with the same conditions when their needs for transfer are different from case to case (logistic approach), or why providers must use the public postal network but not, for example, public transport infrastructure or own postal network.

Therefore it would be useful to consider the postal system in the environment, ie, where is overlapped with other systems (and in what way), what is common and what is different according other compatible systems.

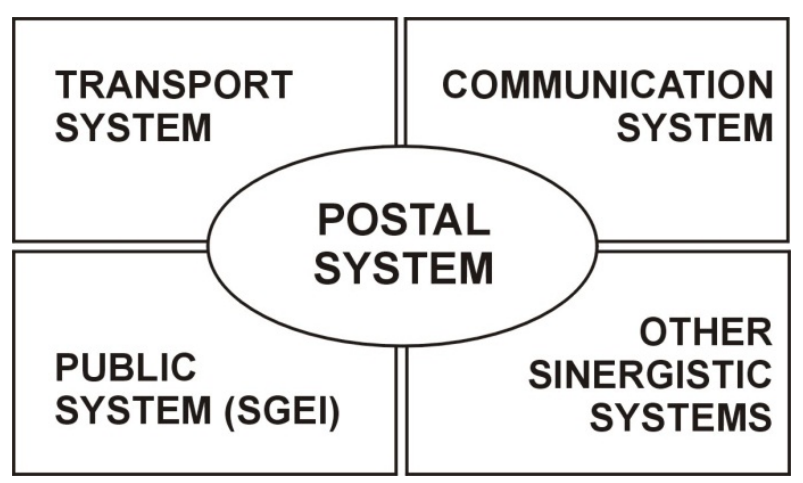

Figure 1 Postal system in an environment (Source: Author)

From the figure we could see that the postal system is the part of the transport system because they share same task - transfer / transport of the transportation subject (people, goods, messages) in the transportation entity (vehicles, envelopes) through a transport (e.g. postal) network according to certain rules and protocols (technology), from the place A to B in real time. [2] Differences between postal and transport system are primarily reflected in the fact that the postal system has not own specific infrastructure (highways, railways,...) and therefore it uses the infrastructure of other transport sectors (the network is a different term then infrastructure) and, unlike other transport sectors, covered the whole territory (with the cellular organization of the entire geographical area). It should also be noted that the postal effects (statistic) are observing and measures in the number of transferred items, pieces, while the transport is measuring in derived units of tons / kilometer and passenger / kilometer. [3]

Certainly, the postal system is the part of communication system because people can communicate through three different channels. For physically presence and communication with another person/s people need to take transportation, for exchanging physical messages people need postal system and for exchanging electronic messages people need telecommunication system. [4] Furthermore, the postal system is part of the public system because postal services belong to the services of general economic interest (SGEI) which all countries in the world guaranteeing to all citizens under the same conditions (also, public administration use postal system for their needs). At the end, it is well known that the postal system sharing a synergistic effect with several other systems, traditionally with banking and financial (especially payment) system and lately, more and more, with trade system.

The basic economic indicators of the postal system (which including postal and courier activities but without other related activities) show that its revenue is about 1\% of GDP and employs about $1 \%$ of all employees, regardless of the point of view (national, European or 
World) [5]. Therefore it is possible to say that the postal system represents a significant share of the overall economic system of the country (or world) and when we added social component - possibility for all people to communicate with each other all around the world we could say that the postal system have very important socio-economic role for whole mankind as well as whole citizens on the national level.

The single European market means the whole territory of all EU Member States where is, in accordance with the Treaty, guaranteed the universal service, form one side, and the freedom to provide services form other side. Therefore, all network services (postal, energy, railway transport, telecommunications...), which has the relevant markets (geographical component) on the national level under state monopoly, must be liberalized to ensure the uniqueness of the European postal market. This project liberalization of network services started in the nineties of last century, in some industries are completed, some in the finalization, and some just starting. In postal sector, this process officially began 1992nd with "The Green Paper on the development of the Single Market for Postal Services" [6] in which EC proposed "changing scenario", briefly, to gradually (by the price / weight limits) liberalized nationals postal market into the single EU market with direct control of national regulatory bodies in order to preserve universal postal obligations and effective protection of users.

European Commission is proposed in 1997 Postal Directive on common rules for the development of a single European postal market and improves the quality of postal services. Directive is amended 2002 with announcements of deadlines for full market opened (FMO) and 2008 where is written that the third Postal Directive is final and will no longer be changed. [1] During this period of twenty years, some states have opened their postal markets earlier, some are thoroughly prepared for the full liberalization of postal markets, while some lived in the hope that competition will not come. Today it is obvious that competition exist on the single European postal market but only between providers of postal services from the Member States which opened the market. However, some studies show that public postal operators continues to be dominated on the national territory with over $90 \%$ of the total turnover, regardless is it FMO or not. [7]

\section{Delineation of the postal system}

According the purpose and objectives of this conference "Open market - challenge for the postal service", we will noted some basic questions on which someone (eg. legislator) need to answering before started to design the national postal system (but without presentation the usual abstract models in the design of artificial systems). Answer on the first question should clearly determinate what belongs to the postal activity and what not belongs to the postal activity or other related and / or synergistic activities such as logistics, transportation, distribution, telecommunications, advertising, banking, commerce and other activity.

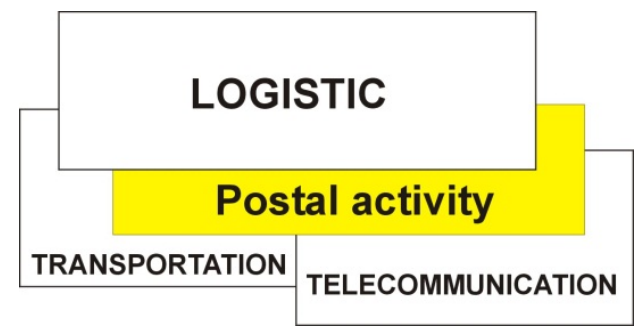

Figure 2 Delineation of related and / or synergistic activities (Source: Author) 
Delineation of postal activities can be carried out in several ways according country specific, for example, based on the description of transportation entities, according the legislative aspect, on the quantitative indicators... Delineation through the subject of transfer / transport can be carried out as follows: Postal - the material entities addressed in the final and the prescribed form which are transmitted from sender to recipient (additional distinction, one E2E technological process). Transport, freight entities that are not in final form and transported from point A (loading) to B (unloading), (additional distinction, "cumulative freight", where each entity has the address but delivered on address of "cumulative freight"). Logistics, material entities which are and are not in final form, but throughout a complex transport process (data store and forward) will be delivered at a specified time at a specific location. From regulatory point of view delineation is possible to carry out throughout the method of contracting. Postal - with adhesion contract (General Terms - everybody with same conditions), Transport - a direct contract between provider and user according Transportation Laws (or Law of obligatory relations), Logistics - agency agreements according users' needs for transportation of all items and freight. Delineation according collect statistic effect has been clarified (pieces or $\mathrm{t} / \mathrm{km}$ ).

With specialization of the postal sector, globalization and liberalization of the postal market should be establish a new paradigm and move away from the concept of the postal system through a previous operational activity of the public postal operator just like how the public postal operator moved away from previous operational activity, for example, transport of people, telecommunications, payment, ... Here are some questions which are help to clarify this issues: when "cumulative freight" is freight transport (e.g. multimodal or integral) and when it became postal service (e.g. consignment), or when that services are shipping or transport logistic activity, but when it the postal activity? How to systematically solve postal money orders which use postal network to transmit money from sender to addressee? Is it postal or financial activity? How to solve a national payment system in the rural areas which is usually carried out through the postal network, but public postal operator is not the official provider of payment system (only banks)? How to regulate the public telecommunications services, such as telegrams? ... European and global postal regulatory practice shows very different approaches to resolving these concerns, but generally, especially European legislations, show that the national postal legislation governing only postal activity in accordance with a defined and clear guidelines of the national postal system.

The next important question is to determine on what criteria will be based definition (and afterwards, regulation) of postal services, for example, on advance prescribed technology during of conveying items (value chains) or on a general formulation - the manipulation with the postal items? Or, other approach, on the benefits which consumers have from the postal service or benefits which providers have (eg based on commercial (profit) activity of providing postal service to third persons), ... During overview of a several EU national legislative solutions, it is clear that in practice doesn't exist unique definition of postal services as well as in postal literature. [8] For example, let's try defined hybrid mail service to find out is it postal or other (which?) service. If we define postal service as a technological process of manipulating postal items, than is postal service, but if we define as a unique process of four value chains: clearing, sorting, transport and delivery of postal items, than is probably not postal service because it hasn't first and, maybe, some other chains. Without discussion is it good or bad for mail industry that the hybrid mail will be not postal service, we should put that service somewhere in other businesses activity (but where). On the other hand, define the postal service as any service associated with the manipulation of "addressed material entities in final form which must to be delivered to the recipient" would be better than definition from traditional postal point of view (value chains) from many aspects, in first 
place, for sustainable of all postal services, innovations in postal industry, statistical monitoring of postal activities, the general interest of the postal system,...

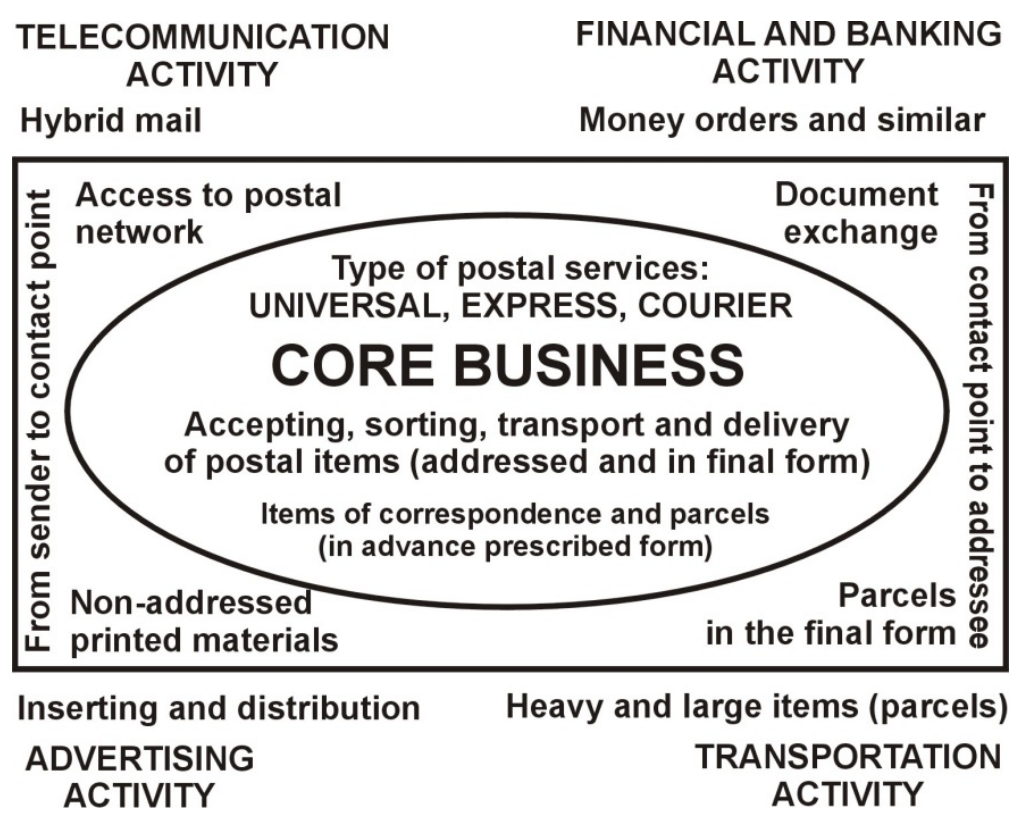

Figure 3 Overview of services which manipulate with the postal items (Source: Author according to Methodological Handbook for the compilation of new postal statistic [9])

Full market opened in postal sector requires effective and efficient regulatory measures which are somehow opposite to each other because, on the one hand, measures must expand free competition on the postal market and, on the other hand, ensure the sustainability of high quality universal services for all users throughout the country. Except well-known public offering, various models of providing of postal services will be appear on the postal market, from the self-provision of services (which sometimes could become a commercial service), up to the providers who will offer postal service with the direct and written contract with the users (bulk mail). In this mix of different ways of providing postal services, legislator certainly should clear identify public postal services and obligate these entrepreneurs to guarantee providing these services to all customers under the same conditions. In the same time legislator should be find the way how will effectively linked those services for universal service obligation (USO) in the aim to ensuring the sustainability of high quality universal postal services throughout the country.

The State had always and will be the competent authority for a universal postal obligation because signed the Universal Postal Convention and therefore it has the duty to create strategy of the national postal policy and set up postal system. In the period before the decision to liberalize the postal market, the government was transferred its international postal obligation to the national postal operator which was previously established and structured for that purpose. In the transition period from the monopoly to the full market opened, State transferred to the NRA (which it also set up by the law) only one part of same obligation but, in the same time, leaved the national postal operator in its property and giving him the exclusive right to the reserved area for the provision of postal services. In the future it may be assumed that the entire universal service obligation (USO) will be transferred to the NRA while the national postal operator will be only one of the many postal providers until it is 
privatized. So, the government proposes and adopts a legislative framework which is implementing throughout national postal policy in accordance with the specific needs of national postal system, but at the same time, government must accept international obligations (SPK, GATS and the EU Postal Directive) and embed in legislative as well. In this complexity it is necessary to clearly define all the resources and connections within the national postal system, which will holistically give effective and optimal results for all stakeholders on the national, European and world level.

\section{New paradigms of the postal system}

The final product of postal activity (sector) is no longer restricted only to the classical (universal) postal service. Express postal services or value added services (depend on national vocabulary) or Courier services (according UN classification of economic activity - ISC or NACE [10]) are mostly mentioned new postal services (however, they existed from the middle of the last century) and they were changed picture of postal sector. But recent new postal products, which manipulate with postal items and generally have no value added (in other words, they are cheaper than conventional postal product), really changing postal industry but somehow (usually because the postal administrations strongly preserved reserved area) these services didn't accepted as postal services. Also, it is obvious that are classic value chain of postal services expanding and usually included the activities that precede it, for example, planning of written communication needs in enterprises (accounts, reports, promotional activities, ...), through the creation of postal items (printing, inserting, sorting) what somehow entered in the classic postal flow, and subsequent activities, such as responses management to written correspondence (analysis, addressing, planning). [5] It is also clear that new technologies, especially ICT, not necessarily substitute traditional postal services but complement them and produce new services or new demand. [4] It is therefore necessary to consider all those issues and decide what to include in the postal sector before start structure design of the postal system.

In this context it should be also consider the restructuring of the national postal operators and public postal network. From the European practice it is not clear unique way how to do that and therefore each NPO for itself, as well as government, must find its own way how requirements from Postal Directive could implemented in national postal policy and design their own national postal system. But generally, the national postal operators from EU are structured as groups of different organizational units that perform a variety of synergistic activities which are based on postal activities, i.e., on the public postal network. On the other hand, the European practice shows that the NPO and Member States simultaneously reconstructing the public postal network in a way that both reduces the number of remaining post offices but increase the number of contracted posts (agencies) with a trend of increasing the number of access points. Consequently, the creator of national postal policy and the owner of an NPO (usually Ministry in charge for the post) and NPO itself must find the optimal solution to this issue during the design of the national postal system.

Certainly it should be noted technological aspects in the creation of a national postal system and need to conduct research of postal services in the public postal network according customer requirements (input-output analysis of postal traffic flow). [12] There are many reasons, from the accurate calculation of the spillover costs of postal services in full and partial technology process from end to end, fulfilling the legal obligations of the separation of cost accounting, analysis and planning through postal traffic flow, for example, in order to improve quality of postal services and the obligation to provide access to the public postal network. In fact, according to the original (real postal traffic flow in the country) it is possible 
to create a model which is able to carry out simulations in order to plan and optimize the postal flow, improve quality, monitor the costs of certain types of services regulated by the optimal model of access to the public postal network...

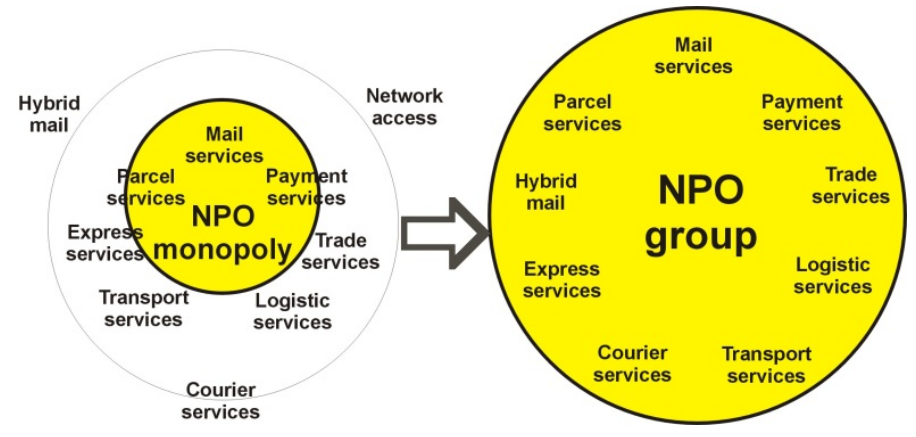

Figure 4 Common portfolio of NPO after restructure (Source: Author)

During the design of the public postal system it is worth considering new concepts and trends in the transport / transfer of material entities such as logistics and intelligent transport systems. Postal system has the aim to ensure a written communication and transport of small quantities of goods from the sender to the addressee and on that way accomplish its tasks: fulfill the guarantee for all people to universal human right to communication, strengthening the country's overall economic system and expanding the social cohesion of society. It is therefore essential that State, as main stakeholder of postal policy and designer of national postal system (and therefore as a part of the universal postal system), establishing a new regulatory postal framework that will satisfy the universal and the national objectives of a new postal system.

\section{Conclusions}

The paper indicates all the usefulness, complexity and necessity of the previous considerations about the vision and mission of the new/reconstructed national postal system. After the general discussion and agreement with all stakeholders on the definition and future tasks of the national postal system it is possible to draw up legislative frameworks that must satisfy both the signed international agreements and national specifics. Thus, the state has a responsibility, as the holder of postal policy and the designer of the national postal system, to align national legislation with EU aqui and other international agreements, but also recognize and integrate pre-defined national specifics into the new/reconstructed postal system. In this context, special attention should be directed to the public, users of the postal system, and avoid the old paradigm of viewing on the postal system only throughout a framework of business of the national postal operator. In other words, the new postal system should ensure to all customers (citizens of the country and the European Union) affordable and quality basic postal services, but also the ability to developing new services, i.e., the possibility of written communication wherever you are, no matter in what form they want to give and regardless of how they want to receive your written communications, all in accordance with different needs, different groups of users for various postal services.

\section{References}

[1] POSTAL DIRECITVE (69/97/EC, 39/02/EC, 06/08/EC)

[2] BADANJAK, BOŠNJAK: OSNOVE PROMETNOG INŽENJERSTVA, FPZ, ZAGREB, 2008.

[3] PERO TABAK: POŠTANSKI PROMET 2, RABUS MEDIA, ZAGREB, 2002. 
[4] PERO TABAK: PREVOZITI LJUDE ILI PRENOSITI INFORMACIJE, LUMIN, ZAGREB, 1996.

[5] TIM WALSH: THE EUROPEAN MAIL MANIFESTO, POSTAL USER'S GROUP, 2006.

[6] GREEN PAPER ON THE DEVELOPMENT OF THE SINGLE MARKET FOR POSTAL SERVICES (COM/91/476)

[7] THE EVOLUTION OF THE EUROPEAN POSTAL MARKET SINCE 1997, ITA CONSULTING GMBH AND WIK CONSULT GMBH, AUGUST 2009

[8] BESIDE MANY POSTAL LAWS IN EU AND WORLDWIDE, TWO DOCUMENTS OF CERP IS VERY USEFULL: A DISCUSSION PAPER ON „POSTAL SERVICE“ DEFINITIONS, CERP WG PT DEFINITIONS, APRIL 2002 AND IMPLEMENTATION GUIDE FOR UNIVERSAL SERVICE, DOC. 13, REV.1, CERP, 2009.

[9] METHODOLOGICAL HANDBOOK FOR THE COMPILATION OF NEW POSTAL STATISTIC, CERP WORKING GROUP FOR STATISTIC, CERP, 2005.

[10]HTTP://WWW.WTO.ORG/ENGLISH/TRATOP_E/SERV_E/POSTAL_COURIER_E/P OSTAL_COURIER_E.HTM AND HTTP://UNSTATS.UN.ORG/UNSD/CR/REGISTRY/REGCS.ASP?CL=27\&LG=1\&CO $=53$

[11]PERO TABAK I TOMISLAV KLJAK: TRAFFIC FLOWS MODEL OF POSTAL ITEMS BASED ON INPUT-OUTPUT DEMANDS INT HE PUBLIC POSTAL NETWORK: CASE STUDY OF CROATIA, TRAFFIC\&TRANSPORTATION, VOL. 21, BR. 6, ZAGREB 2009.. 